\title{
Assessment of Nutritional Composition of Wild Vegetables Consumed by the People of Lebialem Highlands, South Western Cameroon
}

\author{
Afui Mathias Mih*, Abwe Mercy Ngone, Lawrence Monah Ndam \\ Department of Botany and Plant Physiology, University of Buea, Buea, Cameroon \\ Email:^afuimih@yahoo.com,nlmonah77@gmail.com
}

How to cite this paper: Mih, A.M., Ngone, A.M. and Ndam, L.M. (2017) Assessment of Nutritional Composition of Wild Vegetables Consumed by the People of Lebialem Highlands, South Western Cameroon. Food and Nutrition Sciences, 8, 647-657. https://doi.org/10.4236/fns.2017.86046

Received: May 19, 2017

Accepted: June 25, 2017

Published: June 28, 2017

Copyright (c) 2017 by authors and Scientific Research Publishing Inc. This work is licensed under the Creative Commons Attribution International License (CC BY 4.0).

http://creativecommons.org/licenses/by/4.0/

\begin{abstract}
Wild vegetables contribute immensely to the culinary basket and livelihoods of rural communities in sub-Saharan Africa, especially among the people of Lebialem highlands of south western Cameroon where at least 26 such species are consumed as vegetables. To promote the consumption of these vegetables, the nutritional quality of five preferred species in this area, Amaranthus $d u$ bius Mart. Ex Thell., Gnetum africanum Welw., Lomariopsis guineensis (Unerw.) Alston, Pennisetum purpureum Schumach and Vernonia amygdalina Del., was assessed using standard methods. L. guineensis had the highest carbohydrate, protein, calorific value and ash content, and the lowest fat content of $4.05 \%$, very rich in $\mathrm{K}, \mathrm{Ca}$ and $\mathrm{Mg}$ and the amino acids leucine, arginine, lysine, phenylalanine and histidine. The amino acid content was generally higher than $25 \mathrm{mg} / 100 \mathrm{~g}$. Steroids, flavanoids and tannins occurred in moderate to high levels in all five species. Alkaloids and saponins occurred at very low levels, while triterpenes only occurred at very low levels in P. purpureum. The quality of Lomariopsis guineensis, a fern recently reported for the first time as edible is very promising. Pennisetum purpureum, popular as a forage plant, has now been shown to be valuable in the human diet. The study has established the safe and rich nutritional value of these vegetables and that their consumption could combat malnutrition and prevent some of the common nutritionally-related ailments.
\end{abstract}

\section{Keywords}

Nutritional Value, Wild Vegetables, Lomariopsis guineensis, Lebialem Highlands

\section{Introduction}

Wild vegetables constitute all vegetables that are gathered (not cultivated) in- 
cluding species harvested in agricultural areas, uncultivated areas, or forestland [1]. These foods are especially important for the poorest members of user communities, rural populations and women, particularly during critical food shortages. Green leafy vegetables have numerous dietary and health benefits, being very rich sources of essential bio-chemicals and nutrients such as carbohydrates, proteins, vitamins, calcium, iron and palpable concentration of trace minerals [2] [3]. Trace elements that have been implicated in combating a variety of human ailments are found mainly in wild plants especially vegetable [2]. The functional activities of specific organs can be improved by continuous dietary ingestion of trace elements, which could lead to their bioaccumulation at normal or safe levels [3]. Vegetables are one of the cheap sources of energy and form the major portion of human diet, inexpensive and easy to cook [4] [5]. Nutritional analyses show that in many cases the nutritional quality of wild plants is comparable and in some cases superior to domesticated varieties [6] [7]. Odhav et al. [8] have shown that in eight of such vegetables, the mineral content exceeded $1 \%$ of the dry weight and was much higher than for typical cultivated vegetables. Indigenous communities have dietary additives of wild plant material that contain antioxidants to degrade cholesterol from their traditional foods of carbohydrate staples, meat and milk [9].

The biogeographical heterogeneity of Cameroon has given rise to a large variety of flora on which the rural populace depends for food and medicine [10] [11] [12]. The Lebialem Highlands which forms part of the forest agroecological zone of Cameroon is a rich source of a wide variety of wild plants, most of which have hardly been studied from the view point of its uses, proximate composition and nutritional profile [13].

Research, particularly concerning the nutritional aspects of wild-food plants still lacks adequate attention in Cameroon. This raises even great concerns especially when looking at the cases of malnourishment in the country and the extent to which subsistence agriculture is still the norm. Proximate and nutrient analysis of edible vegetables plays a crucial role in the assessment of their nutritional significance. There are also concerns that higher intake of green vegetables may increase ingestion of anti-nutrients such as tannins, phytates and oxalates that impair bioavailability of nutrients or directly cause illnesses or fatality such as haemolysis and even death due to excessive ingestion of lectins [14].

In a recent survey, Ngone et al. [15] identified 26 plant species harvested from the wild that are consumed as vegetables in the Lebialem Highlands. Despite the importance of these plants as a source for nutrients for humans, most of these have not been studied from the view point of proximate composition and nutritional profile. Keeping in mind their medicinal importance, the present investigation was undertaken to ascertain the proximate composition, mineral content and amino acid profile as well as a qualitative assessment of the secondary metabolites to identify any anti-nutritional factors for the top five vegetables in order of taste preference by the inhabitants so as to determine their nutritional quality. 


\section{Materials and Methods}

\subsection{Preparation of Plant Material}

The plants analysed (Table 1) were those earlier identified by Ngone et al. [15] whose voucher specimens were deposited at the Limbe Botanic Garden Herbarium (SCA). Plant materials for analyses were harvested fresh. Leaves were washed under running tap water to remove dirt and air-dried for 10 days. The material was then oven-dried to a constant weight at $72^{\circ} \mathrm{C}$ in a box oven. The dried material was pulverised to a fine powder and stored in air-tight bottles at room temperature until analyses were carried out. For Pennisetum purpureum, young shoots were harvested from the rhizomatous stems. The fibrous outer leaf sheaths were removed until the tender matrix was reached. The matrix was then processed as for leafy samples prior to analysis.

\subsection{Proximate Analyses}

Triplicate samples of each vegetable were used for proximate analysis for crude proteins, crude fibre, total fat, ash, moisture and carbohydrate using standard methods [16]. Moisture content was determined by drying the samples at $105^{\circ} \mathrm{C}$, cooling in a dessicator and weighing the dried sample. The difference between the original weight and the dried weight expressed as a percentage of the original weight gave the moisture content. Crude protein was obtained by determining the nitrogen content using the micro Kjeldahl technique and multiplying the value by 6.25 . Total fat was determined by extracting the material in hexane using a Soxhlet extractor, distilling off the hexane, and drying for 5 days for the remaining solvent to evaporate. The weight of oil left was then expressed as a percentage of the dry weight of the sample [17]. The ash content was obtained by burning a weighed sample in the muffle furnace at $600^{\circ} \mathrm{C}$ until it turned grey-white, weighing the cooled ash and expressing the weight as a percentage of the weight of the original sample. To determine crude fibre, a weighed sample was defatted with a mixture of ethanol and acetone $(1: 1 \mathrm{v} / \mathrm{v})$ and the residue ashed. The percentage of crude fibre was estimated as the difference between the weight of defatted residue and ash expressed as a percentage of the original sample weight. Percentage carbohydrate was determined by the difference method.

The estimated energy value was calculated in kilocalorie (Kcal/100 g) as:

Gross Energy Value $(\mathrm{Kcal} / 100 \mathrm{~g})=5.72 \times($ protein $)+9.5($ fat $)+4.79($ fibre $)+$ 4.03 (carbohydrate)

Table 1. Identity of five wild vegetables most preferred by people of the Lebialem Highlands, Cameroon analysed for nutritional quality.

\begin{tabular}{cccc}
\hline Name & Vernacular Name & Family & Part consumed/Analysed \\
\hline Amaranthus dubius Mart. Ex Thell. & Angews & Amaranthaceae & Leaves \\
Gnetum africanum Welw. & Anoh & Gnetaceae & Leaves \\
Lomariopsis guineensis (Unerw.) Alston & Mandong & Lomariopsidaceae & Leaves \\
Pennisetum purpureum Schumach & Ntisong & Poaceae & Tender matrix of leaf sheaths \\
Vernonia amygdalina Del. & Mekang ndie & Asteraceae & Leaves \\
\hline
\end{tabular}


The macro and micro-elements ( $\mathrm{Na}, \mathrm{K}, \mathrm{P}, \mathrm{Ca}, \mathrm{Mg}, \mathrm{Cu}, \mathrm{Fe}, \mathrm{Mn}, \mathrm{Zn}$, Co and Mo) were analyzed using the atomic absorption spectrophotometer (Perkin Elmer AA Analyst 700), flame atomic absorption spectrophotometer (Model Z5000, Hitachi, Japan) and UV spectrophotometer (Analytikjena SPECORD 205). Samples were digested using wet ashing method with a mixture of perchloric acid and concentrated nitric acid (1:4 v/v), allowed to cool and filtered through No. 42 Whatman filter paper. The samples were each made up to $25 \mathrm{~mL}$ with deionised water and each sample aliquot was then used to determine the elemental content with the atomic absorption spectrophotometer.

For amino acid profile determination, three samples of each of the five vegetables were hydrolyzed under vacuum at $110^{\circ} \mathrm{C}$ for $24 \mathrm{~h}$ in a Pico-Tag apparatus (Waters, Milford, MA, USA) in the presence of $6 \mathrm{~N} \mathrm{HCl}$ containing $0.1 \%$ Phenol, then recovered by water ultra-pure and deposited on an auto tap-parser- 420 trademark Applied Biosystems (Applera Corp., Foster City, CA, USA). The derivation to phenyl isothiocyanate (PITC) was made in pre column. The separation of amino acids was made on a channel HPLC (Applied Biosystems model 172 A: Corp, Foster City, CA, USA) equipped with a column of phase reverse PTC RP-18 $(2,1 * 220 \mathrm{~mm})$ series 238,638, lot no. $02 \mathrm{M}$ 9-40531 Brownlee (Applied Biosystems model 172 A: Corp, Foster City, CA, USA). Solvents used for this analysis were $45 \mathrm{mM}$ sodium acetate, $\mathrm{pH}$ 5.90, and a mixture of 3:7 30\% sodium acetate $105 \mathrm{mM} \mathrm{pH} 4.60$ and acetonitrile. The detection was made at 254 $\mathrm{nm}$ and exploitation of the results were made by the Model 600 Data Analysis System software (Applied Biosystems, Applera Corp., Foster City, CA, USA).

\subsection{Phytochemical Analysis}

For phytochemical analysis, $100 \mathrm{~g}$ of each triplicate powdered sample of the five wild vegetables were weighed and macerated in $1000 \mathrm{~mL}$ acetone for 48 hours. The mixtures were filtered through Whatman No. 1 filter paper and the filtrate concentrated under reduced pressure by rotary evaporation (BUCHI Rotavapor $\mathrm{R}-200$, Switzerland) at $45^{\circ} \mathrm{C}$. Residual solvent was removed by air drying at room temperature and the extracts weighed and stored at $4^{\circ} \mathrm{C}$ until used. The Frothing test for saponins, Cyanidine test for flavanoids, Lieberman-Burchard test for steroids, ferric chloride test for tannins and the Dragendorfs test for Alkaloids were all run using previously reported protocols [18] [19].

\subsection{Statistical Analysis}

Pooled data of proximate and amino acids were keyed in, log-transformed and analysed using SPSS version 16.0 (SPSS Inc. Chicago, IL). Values were given as mean \pm standard deviation of 3 replicates.

\section{Results}

\subsection{Proximate Analysis}

The carbohydrate content of the vegetables ranged from $7.02 \% \pm 0.03 \%$ in $A$. dubius to $55.64 \% \pm 0.32 \%$, in L. guineensis (Table 2). Lomariopsis guineensis 
also ranked highest in protein content (45.34\%) and ash (27.42\%), but had the lowest total fat. Pennisetum purpureum had the highest fibre content of $18.28 \%$ while A. dubius had the lowest. Pennisetum purpureum and Amaranthus dubius have very high moisture contents, recording $89.06 \% \pm 0.03 \%$ and $86.29 \% \pm$ $0.62 \%$ respectively. Lomariopsis guineensis recorded the highest calorific value $(440.37 \pm 1.25 \mathrm{Kcal} / 100 \mathrm{~g})$, followed by Pennisetum purpureum (364.98 \pm 0.48 $\mathrm{Kcal} / 100 \mathrm{~g})$. Lomariopsis guineenis had the highest ash content, closely followed by Gnetum africanum while $A$. Dubius had the least ash content of $1.82 \%$. Total fat ranged from $4.05 \%$ in $L$. guineensis to $14.82 \%$ in P. purpureum.

\subsection{Mineral Content}

The macro element content of the five vegetables are shown on Table 3. $L$. guineensis was very rich in macro elements like $\mathrm{K}, \mathrm{Ca}$ and $\mathrm{Mg}$ while A. dubius was richest in Na, P, Ca and Mg. Gnetum africanum, though generally poor in macro elements, was rich in Na. $P$. purpureum and G. africanum were generally poor in macro elements. They were however relatively rich in micro elements like $\mathrm{Cu}, \mathrm{Fe}$ and $\mathrm{Zn}$ (Table 4). Except for P. purpureum, the Mo content was generally low, ranging from 0.02 to $0.03 \mathrm{mg} / 100 \mathrm{~g}$. $V$. amygdalina was particularly rich in $\mathrm{Zn}$ and $\mathrm{Ca}$ compared to the other vegetables.

\subsection{Amino Acid Content}

The amino acid contents of the five vegetables are shown on Table 5. The results

Table 2. Proximate composition of five wild vegetables consumed by people of the Lebialem Highlands, Cameroon.

\begin{tabular}{cccccccc}
\hline \multirow{2}{*}{ Wild vegetable } & \multicolumn{7}{c}{ Proximate composition (\% \pm SD) } \\
\cline { 2 - 7 } & Carbohydrate & Protein & Total fat & Ash & Fibre & Moisture & Energy value (kcal/100 g \pm SD) \\
\hline Amaranthus dubius & $7.02 \pm 0.03$ & $4.63 \pm 0.08$ & $7.02 \pm 0.06$ & $1.82 \pm 0.10$ & $4.26 \pm 0.27$ & $86.29 \pm 0.62$ \\
Gnetum africanum & $37.53 \pm 1.45$ & $15.12 \pm 0.35$ & $6.38 \pm 0.21$ & $25.37 \pm 0.33$ & $8.44 \pm 0.05$ & $73.01 \pm 0.05$ & $109.78 \pm 0.08$ \\
Lomariopsis guineensis & $55.64 \pm 0.32$ & $45.34 \pm 0.83$ & $4.05 \pm 0.03$ & $27.42 \pm 0.07$ & $15.84 \pm 0.10$ & $71.03 \pm 0.97$ & $268.02 \pm 0.20$ \\
Pennisetum purpureum & $30.85 \pm 0.92$ & $27.05 \pm 0.97$ & $14.82 \pm 0.11$ & $9.06 \pm 0.03$ & $18.28 \pm 0.19$ & $89.06 \pm 0.03$ & $440.37 \pm 1.25$ \\
Vernonia amygdalina & $22.75 \pm 0.30$ & $45.02 \pm 1.02$ & $9.12 \pm 0.17$ & $12.95 \pm 0.07$ & $10.59 \pm 0.41$ & $69.61 \pm 0.71$ & $364.98 \pm 0.48$
\end{tabular}

Values are mean \pm SD of triplicate samples.

Table 3. Macronutrient composition of five wild vegetables consumed by people of the Lebialem Highlands, Cameroon.

\begin{tabular}{cccccc}
\hline \multirow{2}{*}{ Wild Vegetable } & \multicolumn{5}{c}{ Macronutrient content $(\mathrm{mg} / 100 \mathrm{~g} \pm \mathrm{SD})$} \\
\cline { 2 - 6 } & $\mathrm{Na}$ & $\mathrm{P}$ & $\mathrm{K}$ & $\mathrm{Ca}$ & $\mathrm{Mg}$ \\
\hline Amaranthus dubius & $5.59 \pm 0.09$ & $14.00 \pm 0.09$ & $170.82 \pm 0.42$ & $60.02 \pm 0.45$ & $59.85 \pm 0.24$ \\
Gnetum africanum & $1.54 \pm 0.06$ & $0.19 \pm 0.03$ & $0.07 \pm 0.03$ & $4.13 \pm 0.05$ & $0.31 \pm 0.04$ \\
Lomariopsis guineensis & $1.03 \pm 0.05$ & $0.85 \pm 0.06$ & $367.48 \pm 2.57$ & $32.00 \pm 0.03$ & $33.98 \pm 0.08$ \\
Pennisetum purpureum & $0.05 \pm 0.02$ & $0.22 \pm 0.03$ & $0.09 \pm 0.03$ & $3.56 \pm 0.10$ & $1.70 \pm 0.02$ \\
Vernonia amygdalina & $0.06 \pm 0.03$ & $0.93 \pm 0.04$ & $3.62 \pm 0.10$ & $2.12 \pm 0.04$ & $0.59 \pm 0.08$ \\
\hline
\end{tabular}

Values are mean \pm SD of triplicate samples. 
Table 4. Micronutrient composition of five wild vegetables consumed by people of the Lebialem Highlands, Cameroon.

\begin{tabular}{ccccccc}
\hline \multirow{2}{*}{ Wild Vegetable } & \multicolumn{5}{c}{ Micronutrient content $(\mathrm{mg} / 100 \mathrm{~g} \pm \mathrm{SD})$} \\
\cline { 2 - 7 } & $\mathrm{Cu}$ & $\mathrm{Fe}$ & $\mathrm{Mn}$ & $\mathrm{Zn}$ & $\mathrm{Co}$ & $\mathrm{Mo}$ \\
\hline Amaranthus dubius & $0.06 \pm 0.02$ & $0.69 \pm 0.04$ & $0.24 \pm 0.04$ & $0.26 \pm 0.05$ & $0.02 \pm 0.02$ & $0.03 \pm 0.01$ \\
Gnetum africanum & $0.75 \pm 0.09$ & $0.02 \pm 0.02$ & $0.51 \pm 0.03$ & $0.71 \pm 0.02$ & $0.02 \pm 0.01$ & $0.02 \pm 0.02$ \\
Lomariopsis guineensis & $0.33 \pm 0.05$ & $1.32 \pm 0.04$ & $0.52 \pm 0.05$ & $0.80 \pm 0.03$ & $0.05 \pm 0.02$ & $0.03 \pm 0.02$ \\
Pennisetum purpureum & $7.09 \pm 0.04$ & $4.09 \pm 0.03$ & $0.40 \pm 0.10$ & $0.53 \pm 0.07$ & $0.04 \pm 0.03$ & $0.32 \pm 0.03$ \\
Vernonia amygdalina & $0.17 \pm 0.04$ & $0.05 \pm 0.02$ & $0.18 \pm 0.07$ & $0.80 \pm 0.10$ & $0.02 \pm 0.01$ & $0.02 \pm 0.01$ \\
\hline Values are mean \pm SD of triplicate samples. & & & & &
\end{tabular}

Table 5. Amino acid content of five wild vegetables in the Lebialem Highlands of Cameroon.

\begin{tabular}{cccccc}
\hline \multirow{2}{*}{ Amino Acid } & \multicolumn{5}{c}{ Content $(\mathrm{mg} / \mathbf{1 0 0} \mathrm{g} \pm \mathrm{SD})$} \\
\cline { 2 - 6 } & Amaranthus dubius & Gnetum africanum & Lomariopsis guineensis & Pennisetum purpureum & Vernonia amygdalina \\
\hline Arginine & $0.35 \pm 0.04$ & $25.3 \pm 0.48$ & $69.95 \pm 0.26$ & $2.53 \pm 0.07$ & $5.54 \pm 0.08$ \\
Cysteine & $0.09 \pm 0.05$ & $4.79 \pm 0.04$ & $1.35 \pm 0.29$ & $0.26 \pm 0.06$ & $1.77 \pm 0.04$ \\
Histamine & $0.14 \pm 0.05$ & $16.13 \pm 0.18$ & $28.07 \pm 0.13$ & $1.62 \pm 0.08$ & $2.53 \pm 0.09$ \\
Isoleucine & $0.34 \pm 0.06$ & $44.26 \pm 0.08$ & $39.25 \pm 0.42$ & $3.85 \pm 0.12$ & $4.75 \pm 0.05$ \\
Leucine & $0.54 \pm 0.06$ & $45.47 \pm 0.37$ & $102.87 \pm 0.26$ & $5.73 \pm 0.17$ & $9.48 \pm 0.07$ \\
Lysine & $0.35 \pm 0.04$ & $40.05 \pm 0.08$ & $67.04 \pm 0.33$ & $3.14 \pm 0.10$ & $5.24 \pm 0.06$ \\
Methionine & $0.13 \pm 0.06$ & $5.25 \pm 0.23$ & $25.22 \pm 0.24$ & $1.47 \pm 0.05$ & $1.56 \pm 0.10$ \\
Phenylalanine & $0.36 \pm 0.06$ & $28.31 \pm 0.46$ & $67.06 \pm 0.20$ & $3.56 \pm 0.07$ & $3.30 \pm 0.09$ \\
Threonine & $0.27 \pm 0.04$ & $55.81 \pm 0.21$ & $58.26 \pm 0.26$ & $3.48 \pm 0.17$ & $2.25 \pm 0.07$ \\
Trypsine & $0.11 \pm 0.05$ & $26.25 \pm 0.30$ & $6.22 \pm 0.16$ & $0.64 \pm 0.07$ & $0.02 \pm 0.02$ \\
Tyrosine & $0.09 \pm 0.03$ & $6.92 \pm 0.09$ & $52.05 \pm 0.16$ & $4.69 \pm 0.29$ & $4.48 \pm 0.08$ \\
Valine & $0.37 \pm 0.06$ & $32.8 \pm 0.19$ & $51.10 \pm 0.27$ & $5.17 \pm 0.12$ & $5.22 \pm 0.06$
\end{tabular}

Values are mean \pm SD of triplicate samples.

show that Lomariopsis guineensis, Gentum africanum and Vernonia amygdalina had higher amino acid content than either of Pennisetum purpureum and Amaranthus dubius. Leucine, arginine, lysine, phenylalanine and histidine were highest in Lomariopsis guineensis. A. dubius had the lowest amino acid content ranging from $0.09 \mathrm{~g} / 100 \mathrm{~g}$ for cysteine to $0.36 \mathrm{~g} / 100 \mathrm{~g}$ for phenylalanine. For $L$. guineensis, the amino acid content was generally higher than $25 \mathrm{mg} / 100 \mathrm{~g}$ except for cysteine and trypsine where the values were 1.35 and $6.25 \mathrm{mg} / 100 \mathrm{~g}$, respectively. For $V$. amygdalina and $P$. purpureum, the values generally were between 1 and $10 \mathrm{mg} / 100 \mathrm{~g}$.

\subsection{Secondary Metabolites}

Each of the five vegetable species contained four to five of the secondary metabolites except for Lomariopsis guineensis which had just three (Table 6). Steroids, flavanoids and tannins were the most frequently isolated metabolites present in all five species. Alkaloids and saponins occurred in very low concentrations 
Table 6. Qualitative assessment of some secondary metabolites of five wild vegetables most preferred by people of the Lebialem Highlands, Cameroon.

\begin{tabular}{cccccccc}
\hline \multirow{2}{*}{ Vegetable species } & \multicolumn{5}{c}{ Secondary metabolite concentration $^{\mathrm{a}}$} \\
\cline { 2 - 7 } & \multicolumn{3}{c}{ Alkaloids Flavanoids Saponins Steroids Tanins Triterpenes } \\
\hline Amaranthus dubius Mart. Ex Thell. & + & + & - & +++ & ++ & - \\
Gnetum africanum Welw. & + & +++ & + & +++ & ++ & - \\
Lomariopsis guineensis (Unerw.) Alston & - & ++ & - & +++ & ++ & - \\
Pennisetum purpureum Schumach & + & +++ & - & - & ++ & + \\
Vernonia amygdalina Del. & + & ++ & + & +++ & ++ & - \\
\hline
\end{tabular}

${ }^{a}+=$ Low concentration, $++=$ Moderate concentration, $+++=$ High concentration, $-=$ Not detected.

while triterpenes were only found at low levels in Pennisetum purpureum. Steroids were high where ever they occurred.

\section{Discussion}

The proximate analysis of the five vegetables shows that the moisture content was generally high especially for $P$. purpureum and A. dubius. Although high moisture content is necessary to maintain the turgidity of the vegetable cells and thus their freshness, it could adversely affect their shelf live. That notwithstanding, the high moisture content is a welcome phenomenon as this would be able to provide the $20 \%$ of the total water consumption needed to come from food [20]. The moisture content is similar to that of other wild and cultivated vegetables [2] [21] [22]. The five vegetables were generally rich in ash with values of up to $27 \%$. This indicates that the vegetables could be a good source of mineral elements in the diets of consumers. This is further supported by the relatively high content of macro and micro elements of the vegetables. The crude protein content observed in this study was generally higher than the crude protein values recorded for similar studies elsewhere [21] [22] [23] [24] [25]. This shows that these vegetables are a rich source of protein and their consumption could be encouraged to avert protein energy malnutrition common in traditional communities. The crude fibre content ranged from $4.26 \%$ in A. dubius to $18.28 \%$ in $P$. purpureum similar to those reported for other leafy vegetables [23]. Fibre is an important dietary component essential for providing bulk and for the prevention of overweight and constipation as well as reducing the risk of colon cancer and hypertension [26] [27]. Fibre cleanses the digestive tract, by removing potential carcinogens from the body and prevents the absorption of excess cholesterol. Fibre also adds bulk to the food and prevents the intake of excess starchy food and may therefore guard against metabolic conditions such as hypercholesterolemia and diabetes mellitus [28] [29]. Consumption of the vegetables under study here could provide the required dietary allowance of 25 to $40 \mathrm{~g} \cdot \mathrm{day}^{-1}$. Except for L. guineensis with a value of $55.64 \%$, the carbohydrate content of the vegetables were generally low compared to those reported by Satter et al. [21] for species in Bangladesh. The values were comparable to those of vegetables in $\mathrm{Ni}$ geria and Pakistan [24] [30]. Both A. dubius and L. guineensis were very rich in 
both macro and microelements. The elements are variously important in the human diet. $\mathrm{Na}$ and $\mathrm{K}$ are important in the transport of metabolites in the human body. The $\mathrm{Na} / \mathrm{K}$ ratio must be less than 1 to control blood pressure [31]. Apart from G. africanum, this ratio was maintained below 1 for the vegetables studied. This shows that the vegetables could be valuable in ameliorating sodium-related health risks [32]. Ca is needed for the maintenance of bone, teeth, muscle and heart function, while $\mathrm{Mg}$ is required as co-factor in many enzymes, protein and nucleic acids synthesis in the human body. Fe is important for the formation of haemoglobin and for the functioning of the central nervous system. Other trace elements have other vital functions that contribute to human health. The vegetables in this study have varying amounts of these elements that could provide the dietary needs. The results of the amino acid composition show that Lomariopsis guineensis, Gentum africanum and Vernonia amygdalina have higher amino acid content compared to Pennisetum purpureum and Amaranthus dubius. Gnetum africanum and Lomariopsis guineensis are particularly rich in essential amino acids like lysine (main limiting amino acid in cereal grains), arginine, histidine, leucine and phenylalanine similar to Coccinia grandis and Trigonella foenum-graecum [33]. In this study, the secondary metabolites present in the wild vegetable extracts were represented in different proportions. Alkaloids were absent in Lomariopsis guineensis, steroids in Pennisetum purpureum while triterpenes were only present at a very low level in Pennisetum purpureum. Besides the importance for the plant itself, such metabolites determine the nutritional quality of food, colour, taste, smell, antioxidative, anticarcinogenic, antihypertension, anti-inflammatory, antimicrobial, immune-stimulating, and cholesterol-lowering properties [34]. The presence of secondary metabolites probably explains their use as medicinal plants.

Among the plants analysed in this study, the nutritional value of $L$. guineensis, a fern, is being reported for the first time. Although there are edible ferns, this fern has never been reported as edible. Ngone et al. [15] reported it as an edible plant for the first time. The present results show that it is nutritionally rich and relatively safe for consumption. $P$. purpureum has been evaluated nutritionally as an animal feed and it proved to be a good forage species, especially if supplemented with proteins. The results could not be assumed for human nutrition because whereas the livestock cherish the leaf blades, humans cherish the tender matrix of the leaf sheaths whose nutritional composition could be a bit different as demonstrated here. For $V$. amygdalina, $G$. africanum and $A$. dubius there are reports of related studies whose results have either been confirmed or refuted here.

\section{Conclusion}

This study has elucidated the nutritional value of five wild vegetables popular among the people of the Lebialem Highlands, Cameroon. It has established the rich nutritional value of these vegetables as sources of micro and macro elements, roughage, protein and amino acids without anti nutritional factors. Their 
consumption is therefore encouraged. Further studies on toxicity of these vegetables are encouraged to ascertain their possible adverse effects and to confirm some of the ethnopharmacological claims.

\section{Conflict of Interest Statement}

The authors declare that they have no competing interests.

\section{Acknowledgements}

The authors are grateful to the Community Career Development Foundation Cameroon for financial support of this work (Grant No. 108/COCADEF/Food Sources/2014).

\section{References}

[1] Termote, C., van Damme, P. and Djailo, B.D. (2011) Eating from the Wild: Turumbu, Mbole and Bali Traditional Knowledge on Non-Cultivated Edible Plants, District Tshopo, DR Congo. Genetic Resources and Crop Evolution, 58, 585-618. https://doi.org/10.1007/s10722-010-9602-4

[2] Ebert, A.Z. (2014) Potential of Underutilized Traditional Vegetables and Legume Crops to Contribute to Food and Nutritional Security, Income and More Sustainable Systems. Sustainability, 6, 319-335. https://doi.org/10.3390/su6010319

[3] Jimoh, F.O. and Oladiji, A.T. (2005) Preliminary Studies on Piliostigma thonningii Seeds: Proximate Analysis, Mineral Composition and Phytochemical Screening. African Journal of Biotechnology, 4, 1439-1442.

[4] Gupta, K., Barat, G.K., Wagle, D.S. and Chawala, H.K. (1989) Nutrient Contents and Antinutrients Factors in Conventional and Non-Conventional Leafy Vegetables. Food Chemistry, 31, 105-116.

[5] Addis, G., Urga, K. and Dikasso, D. (2005) Ethnobotanical Study of Edible Wild Plants in Some Selected Districts of Ethiopia. Human Ecology, 33, 83-118. https://doi.org/10.1007/s10745-005-1656-0

[6] Maduka, S.M. (2004) Country Report for Tanzania. In: Chikamai, B., Eyog-Matig, O. and Mbogga, M., Eds., Review and Appraisal on the Status of Indigenous Fruits in Eastern Africa, Synthesis Report.

http://www.biodiversityinterna-tional/networks/saforgen/publication

[7] Della, A., Paraskeva-Hadjichambi, D. and Hadjichambis, A.C. (2006) An Ethnobotanical Survey of Wild Edible Plants of Paphos and Larnaca Countryside of Cyprus. Journal of Ethnobiology and Ethnomedicine, 2, 34. https://doi.org/10.1186/1746-4269-2-34

[8] Odhav, B., Beekrum, S., Akula, U. and Baijnath, H. (2007) Preliminary Assessment of Nutritional Value of Traditional Leafy Vegetables in KwaZulu-Natal, South Africa. Journal of Food Composition and Analysis, 20, 430-435.

[9] Johns, T., Mahunnah, R.L.A., Sanaya, P., Chapman, L. and Ticktin, T. (1999) Saponins and Phenolic Content in Plant Dietary Additives of a Traditional Subsistence Community, the Batemi of Ngorongoro District, Tanzania. Journal of Ethnopharmacology, 66, 1-10.

[10] Cunningham, A.B. (2005) Applied Ethnobotany: People, Wild Plant Use and Conservation. Earthscan Publications Ltd., London, 401.

[11] Sunderland, T.C.H., Harrison, S.T. and Ndoye, O. (2004) Commercialisation of 
Non-Timber Forest Products in Africa: History, Context and Prospects. In: Sunderland, T.C.H. and Ndoye, O., Eds., Forest Products, Livelihoods and Conservation: Case Studies of Non-Timber Forest Products Systems, Vol. 2, CIFOR, Africa Bogor, $1-24$.

[12] Onana, J.M. (2011) Vascular Plants of Cameroon: Taxonomic Checklist. In: Flore Du Cameroon, Occasional Volume, IRAD-National Herbarium of Cameroon, Yaounde, 195.

[13] Harvey, Y., Tchieuque, B. and Cheek, M. (2010) The Plants of Lebialem Highland, Cameroon: A Conservation Checklist. Royal Botanic Garden, Kew, UK, 7-31.

[14] Thompson, L.U. (1993) Potential Health Benefits and Problems Associated with Antinutrients in Foods. Food Resources International, 26, 131-149.

[15] Ngone, A.M., Ndam, L.M. and Mih, A.M. (2016) Survey of Wild Vegetables in the Lebialem Highlands of South Western Cameroon. Journal of Plant Science, 4, 172184.

[16] AOAC International (2005) Official Methods of Analysis of AOAC International. 18th Edition, Association of Official Analytical Chemist, Washington DC.

[17] Ani, A.O., Omeje, O.D. and Ugwuowo, L.C. (2012) Effects of Raw Bambara Nut (Voandzeia subter-ranea L.) Waste and Enzyme Complex on Growth Performance and Apparent Nutrient Retention in Broiler Chickens. African Journal of Biotechnology, 11, 11991-11997.

[18] Edeoga, H.O., Okwu, D.E. and Mbaebie, B.O. (2005) Phytochemical Constituents of Some Nigerian Medicinal Plants. African Journal of Biotechnology, 4, 685-688. https://doi.org/10.5897/AJB2005.000-3127

[19] Krishnaiah, D., Devi, T., Bono, A. and Sarbatly, R. (2009) Studies on Phytochemical Constituents of Six Malaysian Medicinal Plants. Journal of Medicinal Plants Resources, 3, 67-72.

[20] Food and Nutrition Board (FNB) (2005) Dietary Reference Intake for Water, Potasium, Sodium Chloride and Sulfate. The National Academies Press, Washington DC, 77-85.

[21] Satter, M.M.A., Khan, M.M.R.L., Jabin, S.A., Abedin, N., Islam, M.F. and Shaha, B. (2016) Nutritional Quality and Safety Aspects of Wild Vegetables Consumed in Bangladesh. Asian Pacific Journal of Tropical Biomedicine, 6, 125-131.

[22] Afolayan, A.J. and Jimoh, F.O. (2009) Nutritional Quality of Some Wild Leafy Vegetables in South Africa. International Journal of Food Science and Nutrition, 60, 424-431. https://doi.org/10.1080/09637480701777928

[23] Acipa, A., Kamatenesi-Mugish, M. and Oryem-Origa, H. (2013) Nutritional Profile of some Selected Food Plants of Otwaland Ngai Sub Counties, Oyam District, Northern Uganda. African Journal of Food, Agriculture and Nutritional Development, 13, 7428-7451.

[24] Onwordi, C.T., Ogungbade, A.M. and Wusu, A.D. (2009) The Proximate and Mineral Composition of Three Leafy Vegetables Commonly Consumed in Lagos, Nigeria. African Journal of Pure and Applied Chemistry, 3, 102-107.

[25] Hussain, J., Rehman, N., Khan, A.L., Hussain, H., Al-Harrasi, A. and Ali, L. (2011) Determination of Macro and Micronutrients and Nutritional Prospects of Six Vegetable Species of Mardan, Pakistan. Pakistan Journal of Botany, 43, 2829-2833.

[26] Mensah, K. and Tomkins, A. (2003) Household-Level Technologies to Improve the Availability and Preparation of Adequate and Safe Complementary Foods. Food and Nutrition Bulletin, 24, 104-125. https://doi.org/10.1177/156482650302400106

[27] Koca, I., Hasbay, I., Bostanci, S., Yilmaz, V.A. and Koca, A.F. (2015) Some Wild 
Edible Plants and Their Dietary Fibre Content. Pakistan Journal of Nutrition, 14, 188-194. https://doi.org/10.3923/pjn.2015.188.194

[28] Vadivel, V. and Janardhanan, K. (2005) Nutritional and Antinutritional Characteristics of Seven South Indian Wild Legumes. Plant Foods for Human Nutrition, 60, 69-75. https://doi.org/10.1007/s11130-005-5102-y

[29] Ishida, H., Suzuno, H., Sugiyama, N., Innami, S., Todokoro, T. and Maekawa, A. (2000) Nutritional Evaluation of Chemical Component of Leaves, Stalks and Stems of Sweet Potatoes (Ipomoea batatas). Food Chemistry, 68, 359-367.

[30] Khan, N., Sultana, A., Tahir, N. and Jamila, N. (2013) Nutritional Composition, Vitamins, Minerals and Toxic Heavy Metal Analysis of Trianthema portulacastrum L., a Wild Edible Plant from Peshawar, Khyber, Pakhtunkhwa, Pakistan. African Journal of Biotechnology, 12, 6079-6085. https://doi.org/10.5897/AJB2013.12972

[31] Food and Agricultural Organization/World Health Organization (2016) Human Vitamin and Mineral Requirements: Report of a Joint FAO/WHO Expert Consultation. Bangkok, Thailand. http://www.fao.org/docrep/004/2809e/y280900.htm

[32] Appiah, F., Oduro, I. and Ellis, W.O. (2011) Proximate and Mineral Composition of Atocarpus altilis Pulp Flour as Affected by Fermentation. Pakistan Journal of Nutrition, 10, 653-657. https://doi.org/10.3923/pjn.2011.653.657

[33] Getachew, A.G., Asfaw, S., Woldu, Z. and Baidu-Forson, J.J. (2013) Dietary Values of Wild and Semi-Wild Edible Plants in Southern Ethiopia. African Journal of Food, Agriculture and Nutritional Development, 13, 7485-7503.

[34] Seigler, D.S. (1998) Plant Secondary Metabolism. Kuwar Academic Press, Dordrecht, New York, 711. https://doi.org/10.1007/978-1-4615-4913-0

Submit or recommend next manuscript to SCIRP and we will provide best service for you:

Accepting pre-submission inquiries through Email, Facebook, LinkedIn, Twitter, etc. A wide selection of journals (inclusive of 9 subjects, more than 200 journals)

Providing 24-hour high-quality service

User-friendly online submission system

Fair and swift peer-review system

Efficient typesetting and proofreading procedure

Display of the result of downloads and visits, as well as the number of cited articles

Maximum dissemination of your research work

Submit your manuscript at: http://papersubmission.scirp.org/

Or contact fns@scirp.org 